\title{
人工膝関節置換術後に生じた大腿骨顆上骨折の治療経験
}

\author{
大分医科大学整形外科 \\ 田 北 親 寛・矢 野 寛一 \\ 藤島英 典・平山隆久 \\ 真 角 昭 吾
}

\section{Supracondylar Fracture of the Femur Following Total Knee Arthroplasty by}

\author{
Chikahiro Takita, Hirokazu Yano, Hidenori Fujishima, \\ Takahisa Hirayama and Syougo Masumi \\ Department of Orthopedic Surgery, Oita Medical University, Oita, Japan.
}

\begin{abstract}
Supracondylar fracture is a serious complication following total knee arthroplasty. Management of this complication is difficult while maintaining good motion. We report our successful experience with a revision arthroplasty using a prosthesis with a long intramedullary stem which allows early motion and rehabilitation.
\end{abstract}

Key words : supracondylar fracture (大腿骨顆上骨折), total knee arthroplasty (人工膝関節置換術), revision arthroplasty（人工関節再置換術）

は じめに

人工膝関節置換術後に生じる術後合併症の一つとし て大腿骨顆上骨折があり，近年その報告例が散見され るようになった。骨折部近傍に人工関節や骨セメント が存在するため手術療法が困難な場合があり、多くは 高齢者のため早期の後療法を配慮しなければならず, 治療に苦慮することが多い，今回我々は，人工関節置 換術後に大腿骨顆上骨折を生じ, 再置換術により良好 な成績が得られた一症例を経験したので若干の文献的 考察を加えて報告する.

\section{症例}

症例 : 80 歳, 女性.

主訴：右膝痛.

現病歷: 昭和 54 年頃から両膝痛が出現し, 両変形 性膝関節症と診断された。保存療法にて経過観察され たが疼痛は軽快せず, 平成 2 年に右膝, 平成 3 年に左
膝の人工関節置換術 (Kinemax。 stabilizer 型 Howmedica 社)（図 1）を施行した。術後, 疼痛は 消失し, 可動域は, 右伸展 $-10^{\circ}$ から屈曲 $110^{\circ}$, 左伸 展一 $10^{\circ}$ から屈曲 $115^{\circ}$ となり, 一本杖歩行にて不自由 なく日常生活を送っていた. 平成 7 年 10 月, 階段か ら $3 \sim 4$ 段下に転落し右膝を強打した，その直後より 右膝痛が出現, 歩行不能となり当科に緊急入院となっ た.

入院時所見 : 大腿骨顆上部に腫脹, 圧痛及び軽度の 熱感があり, 疼痛のために右膝を動かせない状態であっ た.

画像所見: 人工関節置換術施行直後の単純 $\mathrm{X}$ 線像を 示す (図 2). PCL 切除型の stabilizer 型コンポーネ ントを用い，骨セメントにて固定していた．大腿骨前 方の過度の骨切り, いわゆる notch は認められなかっ た. 受傷時の単純X線像（図 3 ) では, 右大腿骨コン ポーネント直上に横骨折を認め, 骨折線は一部大腿骨 コンポーネントの前方フランジ部にも及んでいた。骨 

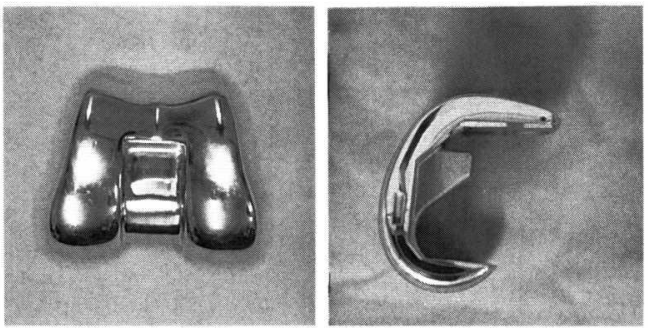

図 1 Kinemax・stabilizer 型大腿骨コンポーネント 顆間部は金属部分で覆われている.
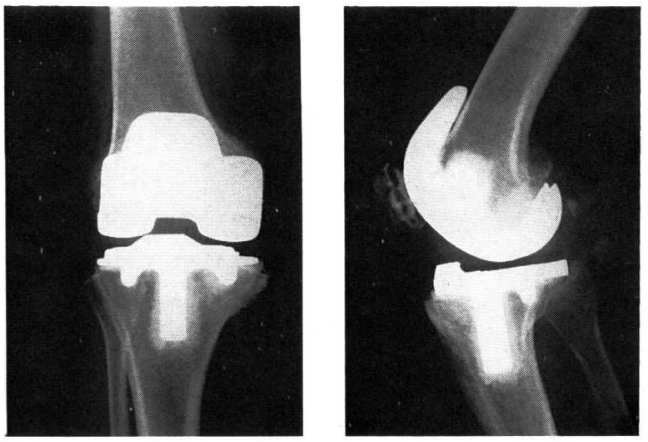

図 2 Kinemax 型人工関節置換術後の単純 X 線像 PCL 切除型の stabilizer 型コンポーネント が用いられ, セメントにて固定されていた. notch は認められなかった。
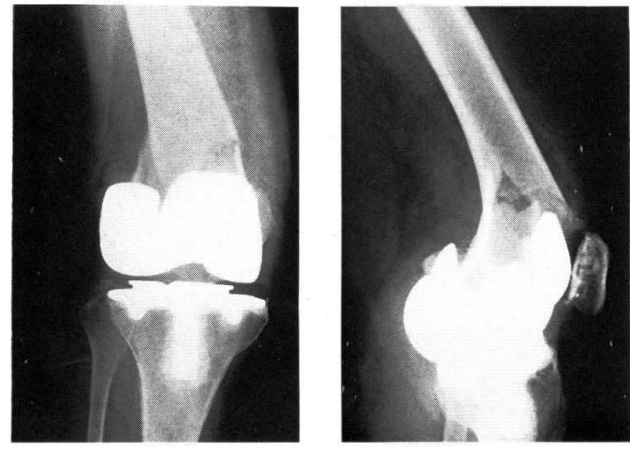

図 3 受傷時単純 X線像 大腿骨コンポーネント直上に横骨折を認め, 骨折部遠位側は外反, 屈曲, 内旋転位してい た.

折部で遠位側は外反, 屈曲, 内旋転位していた。

治療経過：受傷後 3 日目に早期離床と可動域維持を 目的として, 大腿骨側のみの再置換術を施行した. 関
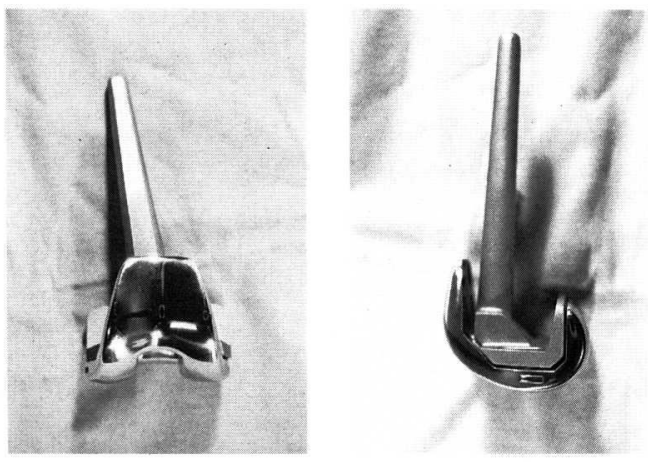

図 4 Long stem 付大腿骨コンポーネント

Kinemax 型は大腿骨コンポーネントに約 12 センチの stem を有したスペーサーをはめ込 み, 骨セメントにて固定し組み立てるように なっている.
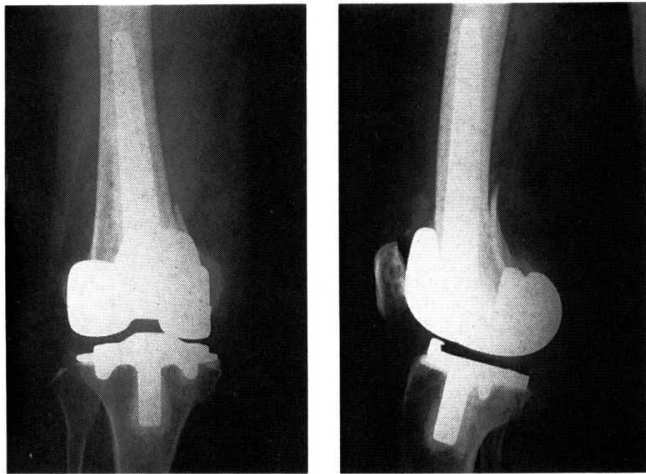

図 5 再置換術後単純 X線像

FTA は $174^{\circ}$ で， stem は骨折部より十分近 位まで挿入されており，良好な固定性が得ら れている.

節を切開すると，大腿骨コンポーネントの直上に一部 粉砕を伴う骨折を認めた。大腿骨コンポーネントと骨 セメントの間にノミを入れコンポーネントを除去する ことで，遠位骨片は一塊に残すことが可能であった。 骨折部を貫く形で long stem 付の大腿骨コンポーネ ント（Kinemax plus と大腿骨スペーサーを使用） （図4）を用い，セメント固定した.

再置換術後の単純X線像（図 5 ）にて，FTA は $174^{\circ}$ となり，良好なアライメントを得ることができた。 stem は骨折部より十分近位まで挿入されており，良 好な固定性が得られた。

術後経過 : 術後 4 日目より可動域訓練および全荷重 
歩行を開始した. 術後 8 週の退院時には可動域は屈曲 $100^{\circ}$, 伸展 $-10^{\circ}$ となり, $\mathrm{T}$ 字杖歩行む可能となり早 期に骨折前の可動域を回復できた. 術後 5 力月目の単 純X線像では良好な骨瘉合が得られている。

\section{考察}

最近では, より機能解剖的な人工関節のデザインの 開発と正確な関節端切除ができる手術器械の普及によ り, 人工膝関節置換術の成績は向上しほぼ $90 \%$ の症 例で良好な成績が獲得できるまでとなった。同時に感 染やゆるみ, 骨折等の術後合併症の発生は重要な問題 となっている，合併症の一つである大腿骨顆上骨折は, Merkelら ${ }^{6)}$ に上るとその頻度は 0.5 2.5\%とされ, 稀 ではあるが治療に苦慮することも多い，本骨折を生じ る原因としては, 大腿骨前面の notch, 骨粗鬆症, 1 ンプラントのデザイン, 膝関節, 股関節の可動域制限 を有する場合, 老人性痴呆等の精神神経疾患の合併例 なら゙があげられている7．本症例に関しては，このよ うな要因は見あたらず, 強力な外力が加わったため骨 折を生じたと考えられる.

治療法に関して, 牽引整復後, ギプス固定等の保存 療法を勧めるもの之, 早期に観血的療法を行った方が よいとするあのがある.

手術療法の成績があまりよいとはいえなかったため に, 以前は保存療法を勧める報告も多く, 1981 年の Hirsh $^{3)}$ は, 良好なアライメントが得られれば, 率 引や cast の保存療法が有用であると述べている。 ま た, 1988 年の Nielsen ${ }^{8)}$ は, 16 例中 6 例に観血的 療法を施行し, そのうち AO plate を使用した 4 例中 3 例が深部感染, 瘦孔形成, スクリューのゆるみによ り術後膝機能不良となったと報告し, 保存的療法を推 奖している.

一方, 最近では観血的療法を勧める報告む多数散見 される. 1985 年のSistoら ${ }^{13)}$ は, ギプス固定を行った 12 例と早期に観血的に内固定を行った 3 例について 検討している.このうち, ギプス固定を行った 12 例 中 8 例に膝機能の著しい低下, むしくは変形癒合を認 めたのに対し, plate 固定を行った 3 例は全てに良好 な骨癒合と膝機能の維持が得られたとし, 保存療法で 十分なアライメントが得られなければ, 観血的に骨接 合を施行するのが良いと述べている。また，1987 年 のCulp ${ }^{2)}$ は, 人工関節置換術後に顆上骨折を生じ た 61 例に対し, 牽引後ギプス固定を行った 30 例と plate 固定・Rush pin 固定むしくは再置換術を行っ た 31 例についてそれぞれ検討し, 保存的療法では変 形癒合・癒合不全・膝痛及び膝機能の低下を生じやす く, 観血的療法による強固な固定と早期の後療法が最 善であると述べている.

本症例では，整復位が得られた状態でギプス固定し た場合, 長期の固定期間が必要と予想され，仮に骨癒 合が得られたとしても高度の可動域制限をきたすこと が危惧された．そのため, 80 歳という高齢であるこ とを考慮し早期に後療法を開始する目的で観血的療法 を選択した。

観血的療法を行う場合には, 骨折の部位, 状態, 転 位の程度, 骨脆弱性を考虑して種々の手術法が選択さ れているようである，骨接合術には， plate 固定 ${ }^{12}$, Rush pin むしくはZickel 釘固定 ${ }^{8)}$, Ender 釘固定 ${ }^{11}$ 等があり, 最近ではIntramedullary nail を用いた固 定法が報告されている(5)1014). plate 固定・Rush pin 固定等の骨接合術は，再置換と比較して手技的に容易 と考えられるが, 強固な固定性を得にくい場合がある. この問題を解決したのが㵦内釘を顆間部より刺入する Intramedullary nail である. 1994 年の Mclaren $^{5)}$ に よると, 7 例の全てにおいて早期の可動域訓練を開始 し， 3 力月で骨折前の膝関節機能を回復できたと述べ ている.

本症例においては, 骨折部が大腿骨コンポーネント 直上であり, plate 固定では強固な固定が得られにく く, Rush pin やZickel 釘ではコンポーネント及び骨 折線に近接する刺入となるため, 固定性の問題之骨折 部の拡大の危険性があると考えられた. Intramedullary nail は, stabilizer 型コンポーネントが用いら れており，大腿骨顆間部が金属部分で覆われているた めに使用できなかった，よって，今回我々は，骨折部 の固定性を得ることのできる再置換術を選択したが, 以前は，長軸を有する大腿骨コンポーネントを用いる には, hinge 型を使用するしかなく，1986 年の泊 $ら^{16)}$ の報告にあるように必然的に脛骨側も再置換術を 余儀なくされていた。 しかし最近では, 再置換術用の long stem を有するコンポーネントが各機種共に作ら れるようになってきており, 大腿骨, 脛骨コンポーネ ント共に種々の組み合わせが可能となったため, ゆる みのない脛骨側は温存し, 大腿骨側のみ置換すること が可能となり手術侵襲を以前より少なくすることがで きるようになった，以上より， long stem を有する大 
腿骨コンポーネントを用いた再置換術は，強固な固定 性を得ることで早期に後療法を開始することができる と考えられ ${ }^{1) 4}$, 人工膝関節置換術後の大腿骨顆上骨 折に対して, Intramedullary nail が使用不能な stabilizer 型コンポーネントが用いられている場合の治 療法として，有用な方法であると考えられる.

\section{ま と め}

1) Stabilizer 型人工膝関節置換術後に大腿骨顆上 骨折を生じ，大腿骨コンポーネントの再置換術を行っ た一症例を経験した。

2 ）Long stem 付大腿骨コンポーネントを用いた 再置換術は, 強固な固定性が得られ，早期に後療法を 開始でき，有用な方法である。

\section{参考 文 献}

1) Cordeiro, E. N., et al. : Periprosthetic Fractures in Patients with Total knee Arthroplasties. Clin. Orthop., $252: 182-189,1990$.

2) Culp, R. W., et al. : Supracondylar Fracture of the Femur Following Prosthetic Knee Arthroplasty. Clin. Orthop., $222: 212-222,1987$.

3) Hirsh, D. M., Bhalla, S. snd Roffman, M. : Supracondylar Fracture of the Femur following Total Knee Replacement. J. Bone and Joint Surg., 63-A : 162 - 163, 1981.

4) Kraay, M. J., et al. : Distal Femoral Replacement With Allograft/Prosthetic Reconstruction for Treatment of Supracondylar Fractures in Patients With Total Knee Arthroplasty. J. Arthroplasty., 7: 7-16, 1992

5) McLaren, A. C., Dupont, J. A. and Schroeber, D. C. Open Reduction Internal Fixation of Supracondylar Fractures Above Total knee Arthroplasties Using the
Intramedullary Supracondylar Rod. Clin. Orthop., 302 : 194-198, 1994

6) Merkel, K. D. and Johnson, E. W. : Supracondylar Fracture of the Femur after Total Knee Arthroplasty. J. Bone and Joint Surg., 68- A : 29-43, 1986.

7）村岡 博, 村上恒二, 生田義和：人工関節置換術後に発 症する大腿骨顆上骨折について.リウマチ科. $6: 27-36$, 1991.

8) Nielsen, B. F., Petersen, V. S. and Varmarken, J. E. : Fracture of the femur after knee arthroplasty. Acta Orthop Scand., 59 : 155-157, 1988.

9) Ritter, M. A. and Stiver, P. : Supracondylar Fracture in a Patient with Total Knee Arthroplasty. Clin. Orthop., 193 : 168-170, 1985.

10) Rolston, L. R., et al. : Treatment of Supracondylar fractures of the Femur Proximal to a Total Knee Arthroplasty. J. Bone and Joint Surg., 77-A : $924-931$, 1995.

11）佐藤 純他：慢性関節リウマチ患者の人工関節置換術 後に発症した大腿骨遠位骨幹部骨折に Ender 釘を使用し た 1 例. 関節外科. $14: 95-98,1995$.

12) Short, W. H., Hootnick, D. R. and Murray, D. G. : Ipsilateral Supracondylar Femur Fractures Following Knee Arthroplasty. Clin. Orthop., 158 : 111-116, 1981.

13) Sisto, D. J., Lachewicz, P. F. and Insall, J. N. : Treatment Supracondylar Fractures Following Prosthetic Arthroplasty of the Knee. Clin. Orthop., 196, $265-272$, 1985.

14) Smith, W. J., Martin, S. L. and Mabrey, J. D. : Use of a Supracondylar Nail for Treatment of a Supracondylar Fracture of the Femur Following Total Knee Arthroplasty. The J. Arthroplasty., $11: 210-213,1996$.

15）土田豊実他：骨・関節・靶帯. 人工関節置換肢の骨折. $6: 917-924,1993$.

16）泊 一秀, 鳥巣岳彦, 藤原 亨：人工関節置換術後の 大腿骨顆上骨折. 整と災. $35: 327-331 ， 1986$. 